Vol. 3, No. 2, Juli 2019, 67-74

Available Online at https://ejournal.warmadewa.ac.id/index.php/kulturistik DOI: dx.doi.org/10.22225/kulturistik.3.2.1199

\title{
GATRA DALAM BAHASA INDONESIA
}

\author{
I Nengah Mileh \\ Universitas Warmadewa \\ milehmenuri@gmail.com
}

\begin{abstract}
ABSTRAK
Bahasa Indonesia memiliki kedudukkan yang sangat penting di Negara Republik Indonesia. Kedudukan yang pertama sebagai bahasa nasional (28 Oktober 1928) dan kedudukan yang kedua sebagai bahasa negara (Bab XV, pasal 36 UUD 1945). Pengembangan dan pembinaan bahasa Indonesia terus-menerus dilakukan dengan berbagai cara. Penelitian gatra sebagai salah satu unsur dalam kalimat merupakan wujud nyata dalam rangka pengembangan dan pembinaan bahasa Indonesia. Penelitian ini bertujuan untuk mendeskripsikan gatra dalam bahasa Indonesia yang meliputi pengertian gatra, ciri-ciri gatra, dan fungsi sintaksis yang diduduki oleh gatra. Teori yang digunakan dalam penelitian ini adalah teori Struktural yang dikembangkan oleh Ferdinand de Saussure. Pandangan-pandangannya terhadap bahasa sebagai objek penelitian dapat disimpulkan dalam bentuk dikotomi-dikotomi sebagai berikut: (1) telaah diakronis dan telaah sinkronis, (2) langue dan parole, (3) sinifiant dan signifie, (4) hubungan sintagmatik dan hubungan paradigmatik. Data dikumpulkan dengan metode simak/pengamatan yang dibantu dengan teknik catat. Data dianalisis dengan metode distribusional dan metode deskriptif sinkronik yang dibantu dengan teknik substitusi dan permutasi. Penyajian hasil analisis dilakukan dengan metode informal dengan teknik induktif dan deduktif.
\end{abstract}

Kata kunci: gatra, Bahasa Indonesia, ciri-ciri gatra, fungsi gatra

\begin{abstract}
[Title: Phrase in Indonesian Language] Indonesian language has a very important position in the Republic of Indonesia. The first position as the national language (October 28, 1928) and the second position as the state language (Chapter XV, article 36 of the 1945 Constitution). The development and founding of Indonesian language is continuously carried out in various ways. Phrase research as one of the elements in the sentence is a real form in the context of developing and fostering Indonesian language. This study aims to describe phrase in Indonesian which includes the notion of phrase, characteristics of phrase, and syntactic functions occupied by phrase. The theory used in this research is Structural theory developed by Ferdinand de Saussure. His views on language as the object of research can be concluded in the form of dichotomies as follows: (1) diachronic study and synchronic analysis, (2) langue and parole, (3) significant and signified, (4) syntagmatic relationships and paradigmatic relationships. Data was collected by observation / observation method which was assisted by note-taking techniques. Data were analyzed by distribution method and synchronous descriptive method which was assisted by substitution and permutation techniques. The presentation of the results of the analysis was done by informal methods with inductive and deductive techniques.
\end{abstract}

Keywords: phrase, Indonesian language, the characteristics of phrase, the function of phrase 


\section{PENDAHULUAN}

Bahasa Indonesia yang dipakai saat ini memiliki kedudukan yang sangat penting, yaitu sebagai bahasa negara/resmi. Hal ini tercantum dalam UUD 1945, Bab XV, pasal 36. Dalam kedudukan sebagai bahasa negara/resmi, bahasa Indonesia memiliki empat fungsi, yaitu 1) sebagai bahasa resmi negara, 2) sebagai bahasa pengantar resmi dalam dunia pendidikan, 3) sebagai alat perhubungan pada tingkat nasional untuk kepentingan perencanaan dan pelaksanaan pembangunan nasional serta kepentingan pemerintahan, dan 4) sebagai alat pengembangan kebudayaan, ilmu pengetahuan dan teknologi (Halim, 1980: 17) .

Di samping berkedudukan sebagai bahasa negara, bahasa Indonesia juga berkedudukkan sebagai bahasa nasional. Dalam kedudukkan sebagai bahasa nasional, bahasa Indonesia, memiliki empat fungsi, (1) Sebagai lambang kebanggaan nasional, (2) sebagai lambang identitas nasional, (3) Sebagai alat penyatuan berbagai suku bangsa yang berbeda latar belakang budaya dan bahasanya ke dalam kesatuan Republik Indonesia, dan (4) sebagai alat perhubungan antardaerah dan antarbudaya.

Mengingat demikian pentingnya kedudukkan dan fungsi bahasa Indonesia, maka pembinaan dan pengembangannya perlu terus-menerus dilakukan dan ditingkatkan baik oleh pemerintah maupun oleh masyarakat. Dalam pengembangan bahasa Indonesia dilakukan dengan cara menyerap unsur-unsur bahasa daerah dan unsur-unsur bahasa asing terutama unsure kosa katanya, sedangkan dalam hal pembinaan telah banyak dilakukan usaha-usaha seperti seminar, lakakarya, lomba, penelitian, kongres bahasa Indonesia.

Pada kesempatan ini, peneliti tertarik untuk meneliti salah satu masalah kebahasaan yang menyangkut sintaksis. Masalah tersebut, yaitu Gatra Dalam Bahasa Indonesia. Masalah ini belum banyak dikenal dan dipahami oleh pemakai bahasa Indonesia. Seperti halnya penelitian-penelitian yang lain, penelitian tentang Gatra ini pun ada manfaatnya bagi pembinaan dan pengembangan bahasa Indonesia. Berdasarkan latar belakang di atas, peneliti menemukan beberapa masalah yang perlu diteliti. Rincian masalah yang akan diteliti, yaitu sebagai berikut: (1) Apakah yang dimaksud dengan gatra dan bagaimana ciri-ciri gatra dalam bahasa Indonesia?, dan (2) Fungsi sintaksis apa yang diduduki oleh gatra dalam bahasa Indonesia?

\section{METODE}

Metode dan teknik yang dipakai dalam penelitian ini dibedakan menjadi tiga, yaitu (1) metode dan teknik pengumpulan data, (2) metode dan teknik Analisis data, dan (3) metode dan teknik penyajian hasil analisis. Pengumpulan data dalam penelitian ini dilakukan dengan metode simak atau pengamatan atau observasi (Sudaryanto, 1993: 131). Data diperoleh dengan cara menyimak pemakaian bahasa Indonesia tulisan pada beberapa skripsi dan media cetak lokal. Metode simak tersebut dibantu dengan teknik catat. Setiap data yang diperoleh dicatat secara ortografis dalam sebuah buku catatan yang telah disiapkan terlebih dahulu. Data yang terkumpul dianalisis dengan metode distribusional. Metode ini merupakan cara kerja yang menghubungkan fenomen-fenomen bahasa itu sendiri, tanpa mengaitkan dengan unsur di luar bahasa. Metode ini dibantu dengan teknik substitusi. Selain metode distribusional, digunakan pula metode deskriptif sinkronis dalam menganalisis data. Data yang bersifat kekinian diolah sesuai dengan apa adanya, tanpa memperhatikan aspek historisnya. Penyajian hasil analisis dil- 
Vol. 3, No. 2, Juli 2019, 69

Available Online at https://ejournal.warmadewa.ac.id/index.php/kulturistik DOI: dx.doi.org/10.22225/kulturistik.3.2.1199

akukan dengan metode informal. Metode informal adalah suatu cara penyajian hasil analisis atau kaidah dengan kata-kata, (Sudaryanto, 1993: 145). Teknik penyajian yang dipakai pada umumnya menggunakan teknik induktif. Teknik induktif adalah cara penyajian dengan mengemukakan hal-hal yang bersifat khusus terlebih dahulu baru kemudian ditarik suatu simpulan yang bersifat umum (Hadi, 1981: 42). Akan tetapi, sekali-sekali dipakai pula teknik deduktif, yaitu cara penyajian dengan mengemukakan hal-hal yang bersifat umum terlebih dahulu baru kemudian dikemukakan hal-hal yang bersifat khusus sebagai penjelasannya.

\section{PEMBAHASAN}

\section{Pengertian dan ciri-ciri gatra}

Mengenai pengertian gatra telah diberikan oleh para ahli bahasa. Beberapa diantaranya dikemukakan berikut ini. Gatra adalah kata atau kelompok kata yang mendukung suatu kalimat (Sulaga, 1982). Linguis lain yang juga memberikan batasan gatra yaitu Yus Badudu dalam bukunya yang berjudul Inilah Bahasa Indonesia yang Benar (1987). Ahli bahasa ini mengatakan gatra adalah bagian (kata atau frase) yang mempunyai fungsi dalam kalimat. Kamus Bahasa Indonesia, menyebutkan gatra adalah lingkungan tertentu dalam kalimat yang dapat ditempati oleh suatu unsure bahasa (Alwi \& Dkk, 2010). Jika diperhatikan batasan ini, hal yang ditekankan untuk menetapkan suatu gatra adalah unsur pembentuk dan fungsi yang diduduki oleh unsur-unsur kalimat tersebut. Berdasarkan beberapa batasan di atas, peneliti mencoba untuk merumuskan sebagai berikut. Gatra adalah bagian kalimat yang dapat berupa kata atau frase yang menduduki satu fungsi sintaksis.

Gatra memiliki ciri-ciri yang membedakannya dengan bagian/penggalan lain yang bukan gatra. Berikut ini diberikan beberapa ciri gatra bahasa Indonesia. 1. Menduduki Satu Fungsi di Dalam Kalimat

Suatu bagian bahasa baik berupa kata maupun berupa kelompok kata dapat dipastikan sebagai gatra kalau telah terbukti menduduki satu fungsi di dalam kalimat. Ciri menduduki satu fungsi ini berlaku untuk semua jenis gatra. Contoh:

(1) Pemerintah berusaha meningkatkan kesejahteraan rakyat.

Kalimat di atas dapat dipenggal menjadi tiga penggalan, (a) Pemerintah, (b) berusaha meningkatkan, dan (c) kesejahteraan rakyat. Ketiga penggalan tersebut masing-masing menduduki satu fungsi, yaitu penggalan (a) sebagai subjek, penggalan (b) sebagai predikat, dan penggalan (c) sebagai objek. Oleh karena menduduki satu fungsi, maka dapat dipastikan bahwa setiap penggalan tersebut di atas adalah gatra.

\section{Merupakan jawaban atas pertanyaan: siapa...? atau apa...?}

Ciri nomor 2 ini hanya dimilki oleh gatra subjek. Jawaban atas pertanyaan siapa...? atau apa...? Pasti merupakan gatra subjek. Oleh karena itu, kita dapat menentukan penggalan mana yang merupakan gatra subjek di dalam suatu kalimat dengan mengajukan salah satu di antara dua pertanyaan ini. Perhatikan kalimat (2 dan 3) di bawah ini.

(2) Dengan demikian, pendapatan negara akan bertambah.

(3) Mereka tertangkap di Cirebon. 
Vol. 3, No. 2, Juli 2019, 70

Available Online at https://ejournal.warmadewa.ac.id/index.php/kulturistik DOI: dx.doi.org/10.22225/kulturistik.3.2.1199

Penggalan pendapatan negara di dalam kalimat nomor (2) termasuk gatra, karena merupakan jawaban atas pertanyaan Apa akan bertambah?. Demikian pula penggalan mereka di dalam kalimat nomor (3) termasuk gatra subjek, karena merupakan jawaban atas pertanyaan Siapa tertangkap di Cirebon?.

3. Merupakan Jawaban atas Pertanyaan: Mengapa...?,atau Bagaimana...?

Ciri nomor tiga ini merupakan ciri gatra predikat. Setiap penggalan kalimat yang dapat menjadi jawaban atas pertanyaan-pertanyaan tersebut pasti merupakan gatra predikat. Perhatikan contoh-contoh berikut ini.

(4) Penduduk desa itu bergotong royong.

(5) Kesehatan beliau agak terganggu.

Penggalan bergotong royong dalam kalimat (4) dapat menjadi jawaban atas pertanyaan: Mengapa penduduk desa itu?. Oleh karena itu, penggalan itu jelas merupakan gatra predikat. Demikian pula penggalan agak terganggu di dalam kalimat (5) di atas termasuk gatra predikat karena dapat menjadi jawaban atas pertanyaan bagaimana kesehatan beliau?

4. Merupakan jawaban atas pertanyaan siapa? atau apa? di belakang predikat.

Ciri nomor (4) ini hanya berlaku untuk gatra objek. Suatu penggalan dapat disebut sebagai gatra objek kalau telah terbukti merupakan jawaban atas pertanyaan: .. siapa? atau ... apa?. Contohnya dapat dilihat pada dua kalimat berikut.

(6) Tersangka terbukti menyelewengkan uang negara.

(7) Polisi telah menangkap pelakunya.

Penggalan uang negara di dalam kalimat (6) merupakan jawaban atas pertanyaan: tersangka terbukti menyelewengkan apa?. Adapun penggalan pelakunya di dalam kalimat nomor (7) merupakan jawaban atas pertanyaan: Polisi telah menangkap siapa?. Oleh karena itu, jelas bahwa kedua penggalan di atas merupakan gatra objek

5. Merupakan jawaban atas pertanyaan-pertanyaan berikut.

- Kapan...?

- Di mana...?

- Dari mana...?

- Dengan apa...?

- Karena apa...?

- Bersama siapa...?

Ciri nomor (5) ini hanya berlaku untuk gatra keterangan. Setiap penggalan

kalimat yang dapat menjadi jawaban atas pertanyaan-pertanyaan tersebut di atas termasuk gatra keterangan. Contohnya dapat dilihat pada beberapa kalimat di bawah ini.

(8) Penyumpahan mereka akan dilakukan lusa.

(9) Seminar tersebut akan diadakan di Denpasar.

(10) Orang itu datang dari desa.

(11) Pemilik toko itu ditikam dengan pisau.

(12) Karena keikutsertaan rakyat, pembangunan jalan itu berjalan lancar. 
Vol. 3, No. 2, Juli 2019, 71

Available Online at https://ejournal.warmadewa.ac.id/index.php/kulturistik DOI: dx.doi.org/10.22225/kulturistik.3.2.1199

(13) Seorang nenek tertimbun reruntuhan tembok bersama cucunya.

Penggalan lusa pada kalimat (8) termasuk gatra keterangan waktu. Dikatakan demikian, karena penggalan ini dapat menjadi jawaban atas pertanyaan kapan penyumpahan mereka akan dilakukan?. Penggalan di Denpasar dan dari desa di dalam kalimat no. (9) dan nomor (10) masing-masing merupakan jawaban atas pertanyaan berikut ini.

- Di mana seminar tersebut diadakan?

- Dari mana orang itu datang?

Oleh karena itu, kedua penggalan tersebut di atas masing-masing disebut gatra keterangan tempat, gatra keterangan tempat tujuan dan gatra keterangan tempat asal. Di dalam kalimat no. (10), ditemukan penggalan dengan pisau, penggalan itu merupakan jawaban atas pertanyaan berikut.

- Dengan apa pemilik toko itu ditikam?

Oleh karena itu, gatra itu disebut gatra keterangan alat. Di dalam kalimat nomor (12) dan (13) terdapat penggalan karena keikutsertaan rakyat dan penggalan bersama cucunya. Kedua penggalan kalimat itu termasuk gatra keterangan. Penggalan karena keikutsertaan rakyat merupakan gatra keterangan sebab sedangkan penggalan bersama cucunya termasuk gatra keterangan penyerta.

\section{Macam-macam Gatra}

Pada subab ini dibicarakan macam-macam gatra berdasarkan fungsi yang diduduki dalam suatu kalimat. Uraiannya secara rinci akan dipaparkan berikut ini. Di depan telah diuraikan bahwa gatra adalah penggalan dalam kalimat yang berwujud kata atau kelompok kata yang menduduki satu fungsi. Fungsi tersebut meliputi subjek, predikat, objek, dan keterangan. Jadi, berdasarkan fungsi yang didudukinya, gatra dapat dibagi menjadi empat, yaitu gatra subjek, gatra predikat, gatra objek, dan gatra keterangan.

\section{Gatra Subjek (GS)}

Di dalam membahas tentang gatra subjek, ada dua hal yang perlu dibicarakan, yaitu pengertian gatra subjek dan Jenis kata yang mengisi gatra subjek. Gatra subjek (GS) adalah penggalan kalimat yang dapat berwujud kata dan dapat pula berwujud kelompok kata yang dapat menduduki fungsi subjek dalam kalimat.

Tidak semua jenis kata yang dapat mengisi GS. Gatra Subjek hanya dapat diisi oleh kata golongan nominal yang meliputi tiga jenis kata, yaitu kata benda, kata ganti, dan kata bilangan. Hal ini terlihat pada beberapa kalimat di bawah ini.

(14) Uang gampang dicuri.

(15) Mereka pergi ke luar.negeri.

(16) Satu diambilnya.

Gatra Subjek di dalam kalimat nomor (14) adalah uang. Kata uang termasuk jenis kata benda. Jadi, kalimat nomor (14) membuktikan bahwa kata benda dapat mengisi GS. Kata mereka pada kalimat nomor (15) dan kata satu pada kalimat nomor (16) masing-masing menduduki gatra subjek. Kata mereka berjenis kata ganti sedangkan kata satu berjenis kata bilangan. Dengan demikian terbukti bahwa kata ganti dan kata bilangan dapat mengisi GS tersebut.

Gatra Subjek yang diisi oleh kata benda, kata ganti, dan kata bilangan yang 
Vol. 3, No. 2, Juli 2019, 72

Available Online at https://ejournal.warmadewa.ac.id/index.php/kulturistik DOI: dx.doi.org/10.22225/kulturistik.3.2.1199

telah dibicarakan di atas adalah GS yang berbentuk tunggal. Adapun GS bentuk kompleks hanya dapat diisi oleh frase. Akan tetapi, tidak semua jenis frase dapat mengisi GS tersebut. Jenis frase yang dapat mengisinya hanyalah frase nominal. Frase nominal adalah frase yang kedua unsur langsungnya golongan kata nominal atau unsur langsungnya golongan kata nominal.

\section{Gatra Predikat (GP)}

Dalam membicarakan gatra predikat (GP) ada dua hal penting yang akan dibahas, yaitu (a) pengertian gatra predikat dan (b) jenis kata dan jenis frase yang mengisi GP. Gatra Predikat adalah penggalan kalimat yang dapat berwujud kata atau kelompok kata yang mendukung ide pokok yang menerangkan dan menduduki fungsi sintaksis predikat. Gatra predikat menerangkan gatra subjek. Ide pokok dalam suatu kalimat dinyatakan oleh gatra subjek dan gatra predikat (Alwi \& Dkk, 2010: 333).

Untuk mengetahui secara lebih jelas mengenai jenis kata dan jenis frase yang dapat mengisi GP dapat diperhatikan contoh kalimat berikut.

(17) Petani menanam padi bibit unggul.

(18) Anaknya pandai-pandai.

(19) Mereka guru.

(20) Anaknya tiga.

Gatra menanam pada kalimat (17) termasuk jenis kata kerja. Gatra pandaipandai pada kalimat (18) termasuk kata sifat. Gatra guru pada kalimat (19) termasuk jenis kata benda, sedangkan gatra tiga pada kalimat (20) termasuk jenis kata bilangan. Jadi, GP yang ada pada kalimat (17-20) diisi oleh kata kerja, kata sifat, kata benda, dan kata bilangan.

Gatra predikat, selain diisi oleh kata kerja, kata sifat, kata benda dan kata bilangan, juga dapat diisi oleh frase verbal (FV), frase adjectival (FA) dan frase nominal (FN). Frase adjektival adalah frase yang kedua unsur langsungnya kata golongan adjektival atau unsur pusatnya kata golongan adjektival.

\section{Gatra Objek (GO)}

Ada dua hal yang perlu dibahas dalam kaitan dengan gatra objek (GO), yaitu (a) pengertian gatra objek dan (b) jenis kata dan jenis frase yang mengisi GO. Uraian selengkapnya dapat diperhatikan berikut ini. Yang dimaksud dengan gatra objek adalah penggalan kalimat yang berupa kata atau kelompok kata yang dapat menduduki fungsi sintaksis objek. GO mempunyai hubungan yang sangat erat dengan GP yang berjenis kata kerja. Gatra objek merupakan pelengkap kata kerja.

Jenis kata dan jenis frase yang dapat mengisi gatra objek dapat dilihat pada beberapa contoh kalimat berikut.

(21) Banyak investor membeli tanah di Bali.

(22) Pemerintah membangun pabrik.

Gatra tanah di dalam kalimat (21) adalah gatra objek, karena dapat menjadi jawaban atas pertanyaan: banyak investor membeli apa?. Jika dilihat jenisnya, ternyata kata tanah berjenis kata benda. Dengan demikian, jelas kalimat (21) membuktikan bahwa kata benda dapat mengisi gatra objek. Begitu pula pada kalimat (22) gatra pabrik dapat menjadi jawaban atas pertanyaan: Pemerintah membangun apa?. Dilihat dari jenisnya, kata pabrik termasuk jenis kata benda. Dengan demikian, jelas kalimat (22) pun membuktikan bahwa kata benda dapat mengisi 
Vol. 3, No. 2, Juli 2019, 73

Available Online at https://ejournal.warmadewa.ac.id/index.php/kulturistik DOI: dx.doi.org/10.22225/kulturistik.3.2.1199

gatra objek.

Kata ganti dan kata bilangan dapat pula mengisi gatra objek. Contohnya dapat dilihat di dalam kalmia di bawah ini.

(23) Negara menanggung mereka.

(24) Saya mengambil satu.

Penggalan kata mereka pada kalimat (23) dapat menjadi jawaban atas pertanyaan, Negara menanggung siapa?. Penggalan kata mereka berjenis kata ganti. Jadi, kalimat di atas memperlihatkan bahwa gatra objek diisi oleh kata ganti. Penggalan satu pada kalimat (24) berjenis kata bilangan. Fungsi yang diduduki, yaitu objek. Jadi, penggalan satu merupakan gatra objek yang diisi oleh kata bilangan.

Pada uraian di atas terlihat bahwa kata golongan nominal (kata benda, kata ganti, dan kata bilangan) dapat mengisi gatra objek. Frase nominal pun dapat mengisi gatra objek. Contoh, perhatikan beberapa kalimat berikut.

(25) Uangnya dipakai membeli buku saya.

(26) Sekarang dia sudah mempunyai rumah besar di Bandung.

(27) Ibu membeli kopi susu

Penggalan-penggalan buku saya, rumah besar, dan kopi susu di dalam kalimat (25-27) termasuk jenis frase nominal, karena kedua unsur langsungnya kata nominal atau unsur pusatnya kata nominal. Ketiganya menduduki fungsi sintaksis objek. Jadi, ketiga penggalan di atas merupakan gatra objek yang diisi oleh frase nominal.

\section{Gatra Keterangan (GK)}

Pokok pembahasan pada subbab ini meliputi dua hal, yaitu (a) pengertian gatra keterangan (GK) dan (b) jenis kata dan jenis frase yang mengisi gatra keterangan. Gatra keterangan (GK) adalah penggalan kalimat yang dapat berupa kata atau berupa kelompok kata yang menduduki fungsi sintaksis keterangan. Gatra keterangan tidak mempunyai hubungan khusus dengan gatra subjek, gatra predikat, dan gatra objek, tetapi berkaitan dengan kalimat secara keseluruhan, minimal dengan gatra subjek dan gatra predikat.sebagai inti kalimat.

Gatra keterangan hanya dapat diisi oleh jenis kata keterangan dan frase preposisional. Contohnya dapat dilihat pada beberapa kalimat berikut ini.

(28) Besok ayah akan pulang dari rumah sakit.

(29) Besok jenazah almarhum akan dimakamkan.

(30) Kemarin terjadi tabrakan di jalan Supratman.

(31) Tadi dia datang ke sini.

(32) Dahulu hidupnya susah.

(33) Data dianalisis dengan metode deskriptif.

(34) Kamu harus belajar dengan tekun.

(35) Pembangunan dilakukan untuk kesejahteraan rakyat.

\section{SIMPULAN}

Berdasarkan uraian pada Bab III di atas, maka dapat disimpulan sebagai berikut. Gatra sebagai salah satu unsur bahasa termasuk dalam wilayah kajian bidang sintaksis. Gatra adalah penggalan kalimat yang dapat berupa kata atau kelompok kata yang menduduki satu fungsi sintasis (Subjek, Predikat, Objek, dan Keterangan).

Gatra memiliki beberapa ciri antara lain, (a) menduduki satu fungsi di da- 
Vol. 3, No. 2, Juli 2019, 74

Available Online at https://ejournal.warmadewa.ac.id/index.php/kulturistik DOI: dx.doi.org/10.22225/kulturistik.3.2.1199

lam kalimat (ciri ini berlaku untuk semua gatra), (b) dapat menjadi jawaban atas pertanyaan siapa...? dan apa...? (ciri ini khusus berlaku untuk gatra subjek), (c) dapat menjadi jawaban atas pertanyaan berikut: mengapa...?, bagaimana...?, berapa...? dan mana...? (ciri ini berlaku untuk gatra predikat saja), (d) dapat menjadi jawaban atas pertanyaan ...siapa? dan ... apa? di belakang GP (ciri ini khusus dipakai untuk gatra objek), dan (e) dapat menjadi jawaban atas pertanyaan: kapan...?, di mana...? dengan apa...?, bersama siapa...?, oleh siapa...?, dan ke mana...? (ciri ini khusus dipakai untuk mengetahui gatra keterangan).

Berdasarkan fungsi yang diduduki dalam kalimat, gatra dapat dipilah menjadi empat, yaitu gatra subjek (GS), gatra predikat (GP), gatra objek (GO), dan gatra keterangan (GK). Gatra subjek dan gatra predikat merupakan inti kalimat sedangkan gatra objek dan gatra keterangan merupakan pendukung/tambahan dari inti kalimat.

\section{DAFTAR PUSTAKA}

Alwi, H., \& Dkk. (2010). Tata Bahasa Baku Bahasa Indonesia. Jakarta: Balai Pustaka.

Hadi, S. (1981). Metodologi Research. Yogyakarta: Yayasan Penerbit Fakultas Psikologi.

Halim, A. (1980). Politik Bahasa Nasional. Jakarta: PN. Balai Pustaka.

Sudaryanto. (1993). Metode dan aneka teknik analisis bahasa. Jakarta: Duta Wacana University Press.

Sulaga, I. N. (1982). Tatabahasa Bahasa Indonesia. Denpasar: SMA Kertha Wisata. 